\title{
Shaping Twenty-first-century Civil Rights Advocacy: Latinos in Metro Atlanta
}

\author{
DAVID A. BADILLO*
}

\section{ABSTRACT}

This article chronicles the Mexican American Legal Defense and Educational Fund's civil rights history in Atlanta and the Southeast from 2000 to 2009 and beyond. It draws on testimonies of MALDEF officials, as well as pertinent historical, social science, and legal scholarship and media accounts, to reveal changing regional Latino migration and settlement patterns and emerging twenty-first-century legal advocacy strategies. Also covered are organized responses to state and local anti-immigrant ordinances passed after September 11, 2001, resistance to residential and workplace discrimination faced by suburban undocumented immigrants, and the fragile nature of coalitions in the contemporary Latino civil rights movement.

Keywords: Mexican-American civil rights, Latino legal advocacy, Latinos in the Southeast.

\section{RESUMEN}

Este artículo hace una crónica de la lucha del Mexican American Legal Defense and Educational Fund por los derechos civiles en Atlanta y el sureste entre 2000 y más allá de 2009. El texto recurre a testimonios de funcionarios del MALDEF. Se parte de estudios académicos pertinentes desde los ámbitos de la historia, las ciencias sociales y el derecho, y también de relatos en los medios masivos de comunicación, para mostrar los patrones cambiantes de la migración y los asentamientos de los latinos, y las estrategias de activismo legal emergentes en el siglo xxI. También se cubren las reacciones organizadas a los decretos antiinmigrantes estatales y locales aprobados tras el 11 de septiembre del 2001, la resistencia a la discriminación residencial y laboral afrontada por los inmigrantes indocumentados suburbanos y la frágil naturaleza de las coaliciones en el movimiento de derechos civiles latino contemporáneo.

Palabras clave: derechos civiles mexico-americanos, promoción y defensa de los servicios legales latinos, latinos y el sureste.

\footnotetext{
* Associate professor and deputy chair of the Latin American, Latino, and Puerto Rican Studies Department, Lehman College, City University of New York (CUNY), david.badillo@lehman.cuny.edu
} 
According to a 1988 National Geographic article, Atlanta, whose population was more than two-thirds black, enjoyed and prided "itself on a degree of racial harmony and cooperation rare among large U.S. cities." Its boosters pointed to it as a "rough-andtumble place, forging ahead, gung ho for progress," a sprawling metropolis of 2.6 million persons with great contrasts between rich and poor. Most important, however, was the "amazing growth of the suburbs [that] has had a centrifugal effect on municipal life, creating satellites that rarely touch the central city" (Zwingle, 1988: 7). In the intervening 25 years, with the influx of Latinos, most of these characteristics have persisted, and, like African-Americans, the newcomers have also developed many successful businesses; unlike them, they have moved into the suburbs in great numbers. Another area where the two groups have differed has been the lack of broad-based civil rights leadership. This article explores the advocacy efforts that have taken place and seeks to contextualize them within larger regional and national developments.

Scholars have noted that in the wake of the 1986 Immigration Reform and Control Act (IRCA), labor markets saturated with newly legalized immigrants (particularly in southern California) saw their residents relocate to other parts of the country. They sought greater economic opportunity, less job competition, and, if undocumented, less likelihood of apprehension. Southern metropolitan areas presented increasingly viable options for settlement. In Atlanta, for example, the construction trades relied heavily on the recruitment of skilled and unskilled workers from Mexico and Latin America to complete the numerous building projects for the 1996 Olympic Games. Over the past decade, roughly half of the immigrants arriving in Georgia have been undocumented, leading to legal and other challenges in a wide range of issues involving immigration status, education, employment, and public policy, all of which necessitated civil rights advocacy (Durand, Massey, and Charvet, 2000; Odem and Lacy, 2009).

In 1999, Antonia Hernández, long-time president and general counsel of the Mexican American Legal Defense and Educational Fund (MALDEF), a UCLA Law School graduate born and raised in northern Mexico, had seen preliminary figures from the upcoming 2000 census confirming the demographic explosion of Latino (mostly of Mexican-origin) migrants and immigrants to the Southeast. She promptly dispatched to the region María Blanco, a MALDEF attorney based in San Francisco, to explore the possibility of expanding the organization's reach into the Southeast. At the time, MALDEF, a non-profit legal advocacy group founded in Texas in 1968, had some 75 employees working in its regional offices in San Antonio, Los Angeles (its national headquarters), Chicago, Washington, D.C., San Francisco (which covered northern California and the Pacific Northwest), as well as smaller satellite offices in Sacramento, Houston, and Phoenix. Blanco, a graduate of U.C. Berkeley's Boalt Hall School of Law, had in prior years gained experience in many areas of civil rights litigation. 
She soon began commuting to Georgia, Alabama, and the Carolinas to observe ongoing efforts in litigation and advocacy to lay the groundwork for opening a fullfledged MALDEF regional office to serve Latino newcomers (Blanco, 2013).

The challenge of building a new civil rights organization required Blanco to diligently study the changing demographics, employment patterns, and other statistics, which she did via monthly trips beginning in early 2000 and lasting until 2002, when the Atlanta office formally opened. She met with leaders of southeastern nonprofit and community organizations, with public interest and civil rights lawyers, and with "just community folks" to determine their main concerns, all the while explaining the nature of MALDEF's work and potential contributions. Blanco noticed that the resident population experienced anxiety over the influx of this new, nonwhite population especially as it "was beginning to flex a little muscle" in Atlanta, Nashville, the North Carolina cities of Charlotte and Raleigh-Durham, and even in Greenville, South Carolina. Immigrants also settled in rural areas, where they worked in agriculture and in the poultry processing industry, as well as in small towns such as Dalton, Georgia, long known as the "Carpet Manufacturing Capital of the World" (Blanco, 2013).

Blanco's exploratory visits coincided with the opening of a MALDEF "outreach office" that served as a liaison between schools and Latino parents and also sought to encourage Latino participation in the upcoming 2000 census. In the previous three censuses, MALDEF had actively monitored Latino participation in the Southwest and Midwest; the results were essential in determining decennial redistricting lines, and thus voting outcomes. In conjunction with the Census Bureau, MALDEF mounted bilingual national television, radio, and newspaper campaigns. This public policy advocacy complemented the organization's litigation campaigns in the area of education, voting rights, and employment, which yielded precedent-setting class action decisions in the 1970s and 1980s that helped alleviate the effects of discrimination against both native-born Latinos and immigrants. It litigated the landmark Plyler v. Doe case, which resulted in a 1982 U.S. Supreme Court ruling requiring states and local school districts to provide free public education to undocumented children (Olivas, 2012). MALDEF was also one of several groups in California to go to federal court and stop the implementation of Proposition 187, the 1994 ballot initiative that restricted benefits (and the constitutional rights) of undocumented immigrants (Badillo, 2005: 10-11).

Of all the possible locations for a southeastern office, Atlanta turned out to be best because of its central location within the region and its setting within the federal court system. The Carolinas and Virginia also contained booming Latino populations, but having the Eleventh Circuit Court of Appeals (with jurisdiction over Georgia, Alabama, and Florida) based in Atlanta offered a huge advantage. Historically, it 
had a more favorable judicial climate than the neighboring Fourth Circuit where, noted Blanco, many judges tended to be "Strom Thurmond picks." Blanco found, though, that even the Atlanta-area courts were "not as sympathetic" as those in Texas, where, somewhat surprisingly, several veteran judges had issued key rulings supporting African-Americans and Latinos in desegregation struggles, bilingual education, and other civil rights issues in decades past. The Southeast, in contrast to Texas and Southwest, had endured no historic legacy of conflict and coexistence between Anglos and Mexicans; nor did it have any prior first-hand experience with Latinos as an ethnic group. Moreover, the region lacked ready litigation targets such as the Texas Educational Agency. These factors made it difficult to determine exactly how to launch a southeastern Latino civil rights movement and develop a litigation agenda. Blanco recalls meeting with lawyers in North Carolina who surprisingly preferred to litigate in state rather than federal courts, especially in cases involving labor and residential discrimination. This contradicted the lessons learned from the prior experience of both African-Americans in the South and Mexican-Americans in the Southwest (Blanco, 2013).

This article chronicles MALDEF's Atlanta efforts by drawing on the testimonies of MALDEF officials, as well as pertinent historical, social science, and legal scholarship, interviews with MALDEF litigators, and media accounts gleaned mostly from The Atlanta Journal-Constitution. The history of the period of between 2000 and 2009 (when MALDEF reluctantly closed its Atlanta office) involves not only changing Latino migration and settlement patterns but emerging twenty-first-century legal advocacy strategies, including those employed to resist state and local anti-immigrant ordinances passed in the wake of the September 11, 2001 attacks and others tied to the ongoing campaign for comprehensive immigration reform. MALDEF contested state and local ordinances regulating the hiring of day laborers, photo identifications, and housing and law enforcement policies not only in northern Georgia but throughout the Southeast. In the process, it not only addressed civil rights issues but at the same time helped expand social, political, and ethnic networks among migrants facing persistent conflicts over civic space and institutional access.

\section{The Urban Context: Atlanta's Pioneer Latino Organizations}

Its economic growth during the 1990s made the Southeast, especially its outlying areas, particularly attractive to newcomers of all stripes, and by 2005, fully 95 percent of its immigrants lived in suburbs (Singer, Hardwick, and Brettell 2008: 311). Major cities such as San Antonio, Los Angeles, Houston, and Denver, and even small towns in 
Texas, southern California, and New Mexico have been important venues of civil rights activity in the past. (Plyler, for instance, emerged in relatively isolated Tyler, a medium-sized East Texas city that hosted a small Mexican immigrant population at the time. In the twenty-first century, however, the large-scale shift to suburban developments has been completed. Urban scholars of the late twentieth century chronicled the rise of Sunbelt metropolises in the post-World War II era in much of the West and South. Meanwhile the annexation of outlying territories became part of a trend of decentralization observable as far back as the nineteenth century, as population spread out from northern cities such as New York to adjacent areas (such as Brooklyn) as either bedroom, streetcar, or a wide variety of other types of suburbs (Jackson 1985). Focusing on the metropolis as a whole provides historians and social scientists with a more precise lens for situating urban life, including civil rights, within broader trends of migration, ethnicity, and geography. This approach helps, too, in understanding Latinos' recent experience in Atlanta, where smaller urban and rural venues increasingly play into overarching patterns of the metropolis.

In the early 2000s, MALDEF's activities in Atlanta, by virtue of its expertise and experience, regional strategy, and connections to national developments, supplanted the legal activities of the consulate and other local groups that had proved effective prior to the demographic surge of the 1990s. Perhaps the most influential of these early groups was the Latin American Association, begun in Atlanta in the 1970s and led by individuals of diverse Latin American origins, including a large number of Cuban refugees resettled away from Miami. That pan-Latino group helped cultivate a pioneer generation of Latino leadership and served tens of thousands annually in its Atlanta headquarters and satellite offices in suburban Clayton, Cobb, and Gwinnett Counties, offering immigration advice as well as housing and employment assistance to an increasingly Mexican-dominant, yet nonetheless diverse, population that also included Puerto Ricans and Colombians. Another group, the MexicanAmerican Business Chamber of Atlanta, founded in 1998 in suburban Norcross, supported numerous Mexican-owned businesses, while the Georgia Hispanic Chamber of Commerce promoted international trade and local entrepreneurs connecting Latino- and non-Latino-owned companies (Bixler, 2002).

As was often the case in the Southwest and Midwest, the office of the Mexican Consul General in Atlanta helped spur institutional development among immigrants, encompassing activities considerably broader than the mundane issuance of visas and overseeing paperwork. María Blanco found that Teodoro Maus, the Atlanta consul general since 1989, was actively engaged in all aspects of "servicios de protección" for Mexican nationals, including investigating complaints of mistreatment and discrimination throughout the Southeast. During the 1990s, as North Georgia's Mexican 
population grew from 30000 to 300000 -the latter figure did not include MexicanAmericans or other Latino communities, which represented another 100 000-, his consular staff had increased from a handful to 24 employees covering South Carolina, Tennessee, and Alabama, as well as Georgia. Maus assisted unauthorized Mexican immigrants in filing for driver's licenses and publicly opposed local ordinances targeting the activities of day laborers working in several suburban north Atlanta towns. Maus, who stepped down in 2002 following the defeat of the Institutional Revolutionary Party (PRI) in Mexico and the advent of the Vicente Fox administration, moved on to head the national Mexican-American Chamber of Commerce and later the Georgia Alliance for Human Rights. Allowing for his lack of resources and the absence of other leadership, he proved to be an effective civil rights advocate. His successor, Remedios Gómez Arnau, continued in his footsteps by seeking adoption of the matrícula consular (consular card) as a legal form of identification for Mexican nationals. The piecemeal advocacy efforts of the consulate, however, were insufficient to serve a growing population within an increasingly complex social, political, and economic landscape that required the mobilization of experienced legal personnel (Bixler, 2000, 2001).

Atlanta, the largest city in the Southeast, had offered plentiful jobs during the 1980s and 1990s in low-wage service and manufacturing industries, but housing, especially in the city proper, proved inadequate for the needs of the newcomers. Latinos, in fact, went directly to the suburban periphery, settling first primarily in inner-ring suburbs in northern DeKalb and Fulton Counties, which together embraced most of the city of Atlanta in their southern portions; then in outlying Cobb and Gwinnett Counties along the Buford Highway and I-85 corridors; and finally in the far northern reaches, such as Cherokee County (Winders and Smith, 2012; Winders, 2005). In the northern DeKalb County towns of Chamblee and Doraville, Latinos, though comprising less than half of the total population, formed an extensive expanding settlement along the Buford Highway. Here, they came to reside near public transportation stops, including the few northern suburban MARTA (Metropolitan Atlanta Rapid Transit Authority) stations. The area connected via regular bus and van service to locations in Mexico and was dotted with businesses noting in their signs diverse regional origins in Mexico, El Salvador, and other homelands. Older immigrants have left apartment complexes for single-family homes in the northern counties. Since 1980, social service agencies, churches, and voluntary and government agencies have served a wide variety of incoming Latino migrants as well as non-Latinos, including many from India, Jamaica, and Vietnam (Mohl, 2003; Dameron and Murphy, 1997).

In response to Latino migration, even relatively small towns came to hold annual processions and observances on December 12 for Our Lady of Guadalupe in 
makeshift churches. Atlanta's archbishop dedicated La Misión Católica Nuestra Señora de las Américas (Catholic Mission of Our Lady of the Americas) on December 12, 1992, which, though affiliated with the nearby Immaculate Heart of Mary Church, served as a de facto Latino national parish, transcending customary ecclesiastical boundaries. More than 500 parishioners regularly attended Sunday mass, and, in addition to pursuing religious interests, the venue's large numbers of undocumented immigrants established social and employment networks that facilitated the sharing of scarce resources. By 2002, 48 of the archdiocese's 110 parishes offered a Spanish mass as Latino Catholics came to outnumber European-origin Catholics in Atlanta (Odem, 2004).

By 2000, most Georgia Latinos had become year-round residents, and, due to greater difficulties in traversing the Mexican border, fewer routinely traveled back to their homeland. Significantly, Atlanta never developed huge barrios for its immigrant population. Settlement patterns differed in several other respects from earlier migrations to other regions, especially with respect to their weaker institutional links with the homeland and with its political as well as church associations. Moreover, there was no previous generation of compatriots in the region on which the newcomers could rely for leadership and mutual aid. Growth remained impressive, however, despite the economic downturn beginning in the mid-2000s. By 2006, there were 700000 Latinos in Georgia (65 percent of them of Mexican origin) and 467000 in the metro area.

\section{Civic Engagement and Advocacy:}

\section{The Southeastern Latino Civil Rights Strategy}

María Blanco, MALDEF's national counsel who first guided the Atlanta office and set the stage for MALDEF's presence in the Southeast, took a broad yet realistic view of the organization's history and trajectory. While recognizing the challenges faced in the region, she also hoped that the office would at the outset take on important cases. The fact that none emerged during the first decade of the twenty-first century was not due to inactivity or inexperience. Rather, the times had changed and so, too, had strategies and practices of legal advocacy and litigation. Egregious instances of segregation, while increasingly rare, were more easily addressed. MALDEF's lawyers in the Southeast soon intervened with local school districts to avoid lengthy, expensive, and (from the defendants' point of view) ultimately unsuccessful outcomes. Blanco recalls, for example, informing one North Carolina kindergarten principal of the illegality of turning away Spanish-speaking students merely because their parents 
could not speak English. "Educational institutions," she observed, "were completely uninformed, [but] once they figured things out they adjusted" (2013).

Another problem area concerned police treatment of immigrants at traffic stops, where Latinos were often asked for social security cards in order to catch them in possession of falsified documents, a deportable offense. This, Blanco says, amounts to an unreasonable penalty for a minor traffic offense. Such everyday encounters resulted from overzealous policing, a practice MALDEF helped to curb. Blanco hoped that somehow several cases could be "keyed up" in the litigation pipeline so that the Atlanta office could hit the ground running, but conceded that litigation was not the organization's primary tactic in settling issues. Instead, change occurred first through "community education and leadership development" based on "community-based civil rights lawyering." In sum, Blanco found that the opening of the Atlanta office coincided with public recognition of "the shock of this first wave," which caused previous residents to wonder, "What just happened? My town just turned brown and there are people speaking Spanish!" (2013).

In 2002 in Fulton County, just as MALDEF began its full-fledged operation in Georgia and the Southeast, Mexican-American Democrat Sam Zamarripa won a seat in the state Senate, along with a Puerto Rican and a Cuban in the Georgia assembly, all first time occurrences (Rodriguez, 2002). While each of these individuals served only briefly in the legislature, the experience of Zamarripa, former head of Atlanta's Latin American Association, is worth recounting because he had already served on MALDEF's Board of Directors for several years prior to his election. (The board is the body that determines litigation priorities and other aspects of governance.) Zamarripa, an investment banker whose grandfather was Mexican and who was born in Fort Benning, Georgia, embraced a unique vantage point vis-à-vis the progress of Latinos in the Southeast as well as their struggle for civil rights. He found that "the speed of change in the South is intersecting with the ambitions and the appetite of the Latino workers." The South's fast-moving regional landscape, he believed, should therefore update its historic belief that it needed "cheap labor" to survive by whole-heartedly embracing the new immigrants. He described the "Nuevo New South" as consisting of dispersed Latino communities "integrating the [remnants] of the Old South with the powerful [immigrant] culture." Although Atlanta-area Latinos lacked the "native elites" that had formed the business backbone of Mexican-American communities in southwestern cities such as Laredo and San Antonio, Zamarripa noticed positive signs of entrepreneurship in the growth of Latino-owned businesses in the construction industry. In the cultural sphere, he pointed to significant intermarriage between Latinos and non-Latinos as paving the way to a new kind of immigrant assimilation (Zamarripa, 2003). 
Zamarripa's initial legislative priorities targeted educational improvement and economic expansion, especially positioning Georgia for increased trade with China. Immigration, however, soon emerged as a key issue throughout his two terms as state senator. When federal control of immigration policy "goes awry," he noted, the states and immigrants will suffer. He was disappointed with the state legislature for refusing to pass his bill that would have allowed undocumented residents without social security numbers to get driver's licenses, which he considered important for public safety. Despite having become the unofficial face of the opposition to Senate Bill 529 in 2006 and having served briefly as a player in the halls of the Georgia legislature, Zamarripa withdrew from politics after his second term to return to the private sector (Jacobs, 2006). Personal and professional circumstances led him to fall short of his goal of making MALDEF as widely known in Atlanta as it was in San Antonio and Los Angeles. He had unsuccessfully pressed the board to maintain a higher profile of the organization and to seek litigation strategies that would result in a "major class action case impacting the larger workings of the U.S. legal and political system" (Zamarripa, 2003).

The 2000 census had confirmed the demographic explosion in the Southeast, and this, along with growing concern for the civil rights of the undocumented, provided new opportunities for litigation and advocacy. In 2002, after Blanco's exploratory visits had paved the way for a permanent office and she had returned to California, MALDEF's Atlanta headquarters opened officially under the direction of Tisha Tallman, a Mexican-American from the Midwest, who became southeast regional counsel. At the beginning of her tenure, Tallman wanted MALDEF to be seen as part of a larger coalition between Latinos and African-Americans. She scheduled educational forums with administrators and parents as well as legislators that pooled resources and expanded community networks. Tallman early on settled several education cases out of court. Educational access remained particularly challenging with Latino graduation rates hovering around only one-third. Georgia Latinos tended to leave high school before graduation due to a lack of understanding of the school system, excessive residential mobility, and the language barrier. Their unauthorized status meant, moreover, that many students, even if they met academic requirements, would remain ineligible for higher education scholarships and affordable in-state tuition rates (Bohon, Macpherson, and Atiles, 2005; Salzer, 2013).

Tallman noted that whereas MALDEF worked with national groups such as the NAACP Legal Defense Fund (LDF), the League of United Latin American Citizens (LULAC), and the National Council of La Raza (NCLR), those organizations never established a strong local presence with permanent offices in the Southeast, even in Atlanta. MALDEF sought to merge within the rich, preexisting civil rights infrastructure and develop a 
coalition of grassroots organizations focusing on the issue of racial profiling and joining in a statewide "right-to-vote" campaign for "felony enfranchisement," which had previously been considered exclusively an African-American issue. Tallman broke new ground by taking on local immigration ordinances targeting the Latino community in overly-broad "dragnets." She noted, "Local officers aren't trained to recognize or deal with fraudulent documents. That's something for [federal] immigration officers to handle." Failing to recognize jurisdictional boundaries eroded trust between police departments and communities and discouraged the reporting of crimes. Day laborers and domestic violence victims would never come forward as long as local officials enforced immigration laws (Tallman, 2005). Even Gwinnett County police agreed that determining the legal status of arrested persons remained the responsibility of the U.S. Immigration and Customs Enforcement Agency (ICE) on behalf of the Department of Homeland Security (McCarthy, 2004).

After three years at the helm, Tallman reflected that MALDEF's activities were having a favorable impact: "To the day laborers [in Georgia and Virginia], the outreach that we're doing is the only outreach that is being done at all." Tallman noted that "nearly every day laborer has at one time or another worked a full day and not received full pay. ... But there hasn't been an organized attempt, on a large scale, to educate them [on how to respond in defense of their rights]." The office also worked to alleviate recurrent violence against Latino agricultural farm workers in South Georgia and advocated on behalf of Latinos unable to obtain the proper identification needed to set up bank accounts, which resulted in their carrying cash and hence becoming more vulnerable to robbery (Tallman, 2006; Brett, 2004). MALDEF, along with the Mexican consulate, had joined in an effort to produce wallet-sized cards for distribution at day laborer pickup spots. The cards contained a list of Spanish-language help hotlines and space for day laborers to write down the name, license plate number, and address of places worked, which would also help encourage the reporting of robberies, unpaid work, and other infractions (Feagans, 2005a). The Atlanta office also tried to shape workers compensation laws; in one situation, MALDEF represented three Georgia slaughterhouse workers denied benefits based on their perceived immigration status. Local cases, Tallman believed, should serve as models for other states throughout the region (Tallman, 2005).

Tallman acknowledged the vision of MALDEF's founders who, she believed, understood the importance of measuring public policy vis-à-vis litigation. She concluded, "A lot of what we do may have been done ten or twenty years ago [elsewhere], but we're doing it in a different context and a different period, which raises challenges but also opportunities." Educational forums proved important as well, whether in higher education or with respect to limited English-proficiency issues in elementary and secondary schools: "As a result of our litigation in Virginia, two schools changed 
their policies and [more] will follow suit in the near future because we continue to be involved" (Tallman, 2005). One important non-litigation tactic concerned the development of MALDEF's Parent School Partnership Program (PSP) in Georgia, which sought to give parents tools for advocating on behalf of their families. The 16-week PSP program alerted them to the perils of standardized testing as well as the right to request a review of student records. PSP-trained parents were assigned translators and received guides to help them prepare for parent-teacher conferences. One MALDEF staffer in charge of the program noted, "Parents don't know that in the same classroom, there are kids who are in different levels. We focus on the elementary schools because high school is a bit late." She helped the students realize the importance of preparation for getting a higher education. Some school officials requesting MALDEF's involvement in their districts, most often due to the districts' need to adhere to requirements of the federal mandates of the No Child Left Behind Act of 2002, were "wonderful people who really want to have the Latino community involved." However, other parents of non-Latino students voiced their disapproval of the immigrant presence by pulling their children from school (Sance-Valverde 2005).

For Latino immigrants and for the MALDEF, from the outset, the year 2006 seemed ominous. Debate opened with a lengthy public hearing on the Georgia Security and Immigration Compliance Act (sB529), which steadily passed through the state legislature. Tisha Tallman labeled the proposed legislation unconstitutional, claiming that the state was "attempting to preempt the federal government's immigration authority." MALDEF was unable to mount a successful challenge to the senate bill, provisions of which at first targeted large employers and, beginning in 2008, the smaller ones as well (Campos, 2006; Campos and Tharpe, 2006). However, some 50000 people gathered on April 10, 2006, at the Plaza Fiesta Shopping Mall along "La Buford" (Buford Highway) in favor of allowing a path to citizenship, while simultaneously protesting the Georgia Security and Immigration Compliance bill that would inevitably accelerate deportations. Nonetheless, the statute passed easily, instituting work eligibility verification requirements that prohibited employers from claiming as a tax deduction any wages paid to any newly hired public employees, contractors, and subcontractors who could not prove their legal presence (Tharpe, 2006; Odem, 2008).

\section{Civil Rights on the Road To Comprehensive Immigration Reform}

During the 1970s and 1980s, MALDEF had emerged on the national stage as a feared and powerful defender of Mexican-Americans, mounting vigorous litigation cam- 
paigns that enervated lingering de facto school segregation throughout the Southwest and granted greater access to voting rights while challenging discriminatory redistricting schemes. With the acceleration of undocumented immigration from Mexico, as well as immigrants and refugees from El Salvador, Guatemala, and other Central American countries, MALDEF became the voice of non-citizens and non-Mexican Latinos as well. The organization also came to share the spotlight with other organizations as its legal focus completed the shift from its earlier exclusive emphasis of Mexican-American desegregation and voting rights struggles to efforts on behalf of preserving the civil rights of unauthorized immigrants. The first decade of the twenty-first century proved to be a trying time for MALDEF -nationally and for its Atlanta office- as a more restrictive civil rights climate emerged in the aftermath of September 11, 2001, which contributed to diminishing MALDEF's resources even as it enhanced the need for advocacy. The organization was still effective in forestalling the more obvious instances of discriminatory actions and legislation by states and localities; however, funding for litigation became scarce.

Despite its illustrious history of civil rights victories (most notably Plyer v. Doe in 1982), MALDEF was forced by circumstances early in the twenty-first century to join with -and sometimes follow the lead of- other litigants such as the American Civil Liberties Union, whose focus on immigration issues included the case of Hazleton $v$. Lozano in Pennsylvania in conjunction with the Puerto Rican Legal Defense and Education Fund, the suburban Dallas litigation in Villas at Parkside v. City of Farmers Branch, and other lawsuits in southern California, Texas, and the Midwest. Mexican migrants remained in limbo, unable to chart a path out of the shadows of undocumented status yet unable to return to their homeland without the risk of losing everything. Local ordinances to regulate day-labor sites and restrict access to mobile homes and apartment house complexes, along with new alien registration and reporting requirements, reflected abiding concerns over perceived unwillingness of newcomers to assimilate. This was not entirely new: in 1999 the northern Atlanta suburbs of Chamblee, Marietta, and Roswell passed ordinances limiting pickup sites for workers. In Atlanta itself, MALDEF had intervened to avoid deportations and arrests, in one notable case in a Home Depot parking lot (Bixler, 1999).

Tisha Tallman stepped down after four years as Southeast Regional Counsel to work for a private firm at the same time that her sister, Anne Marie Tallman, resigned after a brief term as president and general counsel. She was eventually succeeded by Elise Shore, a former prosecutor who presided over the final stretch from 2007 until April 2009. In her first month on the job, Shore spoke out against Gwinnett County's new ordinance requiring contractors to ensure that the undocumented were not hired on public works jobs. She also opposed an anti-loitering ordinance in 
Cherokee County (in the far north of metro Atlanta) that prohibited day laborers from gathering. Cherokee County passed restrictive rental ordinances compelling landlords to check on renters' immigration status and providing for fines or revocation of landlords' licenses if found to be renting to the undocumented. Shore judged this to be clearly unconstitutional and filed a lawsuit in 2007 challenging landlords' right to investigate the legal status of family members at a mobile home park. Local governments, MALDEF argued, lacked authority to establish penalties for "harboring" or "aiding and abetting" the undocumented, which remained exclusively a federal matter (Pickel, 2009, 2007). Property owners, employers, and others in private and public capacities on local levels lacked authority to make determinations on immigration status. MALDEF's legal brief, gleaned from prior experience in southern California and similar challenges throughout the country, listed a host of alleged violations: of Fourteenth Amendment equal protection guarantees; of the Civil Rights Act of 1964 and subsequent federal and state fair housing laws; and of Fourth Amendment search and seizure protections (Robert Stewart v. Cherokee County, 2007).

Such unenforceable local ordinances placed local business owners in the predicament of potentially violating either federal civil rights laws or local laws. Moreover, according to legal scholars -and this point also came up in Plyler-, immigrant families consisted of individuals of "mixed" immigration status within the same household. Therefore, if a landlord refused rental after failing to confirm the status of one of the members, the result could be the unconstitutional denial of rights to citizens and others with a verified legal presence (Olivas, 2011). Although the legal expense and the final outcome of Cherokee County's mobile home challenge became increasingly worrisome to county officials, they continued to fight the preliminary injunction in 2007 that barred enforcement pending a final decision from the Third Circuit Court of Appeals in the Hazleton case (Moscoso, 2006).

MALDEF followed other issues closely in Atlanta, including measures declaring English as Cherokee County's official language and targeting landlords in still unincorporated areas who rented to the undocumented, which proved ineffective and futile -indeed the proposals in Cherokee County were never actually implemented (Poole, 2006). Such policies inhibited full civic engagement by complicating transportation arrangements and access to jobs, churches, and needed family services. In 2008, Regional Counsel Shore warned that the mere act of driving an automobile not only brought Georgia's undocumented to the brink of deportation but created "an incentive for racial profiling," since "you can't tell if someone is driving without a license just by looking [at them]" (Pickel, 2008). One newspaper account included an interview with a Latino car salesman on the Buford Highway reflecting prevalent strategies adopted by immigrants to circumvent residency requirements. The salesman 
suspected that most of his Latino customers brandishing out-of-state "certificates of driving" actually lived in nearby Gwinnett County rather than Tennessee, where unauthorized immigrants and foreign visitors could for a brief spell readily obtain such provisional licenses. Such loopholes, however, quickly closed (Feagans, 2005b). MALDEF's Atlanta office also monitored issues of guest-worker exploitation in farming and also in poultry and in the crabbing industry on the coast of the Carolinas. Workers with temporary H-2A visas were recruited from Mexico to work in the Southeast by Tyson and other big companies under IRCA's guest worker provisions. Meanwhile, companies recruited and hired undocumented workers in violation of the $1986 \mathrm{Im}$ migration Reform and Control Act.

It remains difficult to predict from where, or when, the next big case or civil rights movement will emerge in any region -or if indeed a Latino Brown v. Board of Education is on the horizon. In 2006, President and General Counsel John Trasviña (who replaced Ann Marie Tallman, Tisha's older sister) sought to double the Southeast's "litigation capacity" within five years by "beefing up" staff and creating additional partnerships with private attorneys" (Varela, 2006). In ensuing years, MALDEF became involved in litigation in Arizona, which consumed considerable human and financial resources and contributed significantly to the closing of the Atlanta regional office in April 2009 (and also, at roughly the same time, of Sacramento's satellite office monitoring that state's legislative activities). The closing was due to several factors: lack of finances and the need to devote resources to struggles emerging in Arizona made it increasingly difficult to monitor local developments. Dispatching MALDEF lawyers to the Southeast proved less effective than engaging in hands-on litigation and advocacy, including face-to-face meetings with potential plaintiffs to formulate strategies, and including also discussions with legislators and leaders of community organizations concerning local impacts of federal policies (Blanco, 2013).

Georgia followed Arizona's lead with the passage of its own copycat legislation by doubling down against the presence of undocumented immigrants. In 2011, Georgia legislators, concerned with blocking the undocumented from competing for jobs with U.S. citizens, disappointed with discussions over the progress of border security, and not eager to explore pursuing a path to citizenship for recent immigrants, passed HB87 (The Illegal Immigration Reform and Enforcement Act). This statute expanded the use of E-Verify to the private sector and authorized state and local police to investigate the immigration status of suspects they believe have committed state or federal crimes and who could not produce identification, such as driver's licenses or passports. The U.S. Justice Department, however, in contrast to its response to Arizona's passage of sB1070, never joined litigation to stop implementation of the 2011 Georgia statute. The ensuing lawsuit, to which MALDEF was not a party, resulted 
in an August 2012 Eleventh Circuit three-judge panel ruling upholding the constitutionality of allowing state and local law enforcement authorities to investigate the immigration status of suspects believed to have committed state or federal crimes, while invalidating those sections dealing with the "harboring" and transporting undocumented residents, which fell within the purview of federal immigration authorities (Redmon, 2012).

An important element in the current debate over immigration involves aspects of the Supreme Court's June 2012 ruling in Arizona v. United States. Legal scholar Lauren Gilbert argues that the Arizona ruling served to acknowledge the importance of genuine ties that immigrants had in communities. It downplayed the merely formalistic interpretations of national sovereignty while validating a model of immigration "that would offer a pathway to legal status to undocumented persons within our borders who have put down roots, raised families, and shown themselves to be reliable and productive members of society" (2013: 300). Gilbert views the initiative begun in 2012, Deferred Action for Childhood Arrivals (DACA), which provides for temporary, renewable work authorization and status adjustment, as partially designed to ameliorate the potentially harsh effects of the Arizona law and its copycats in other, mostly southern, states. Tens of thousands of undocumented Georgia immigrants and almost half a million people nationwide, most of them of Mexican origin, have applied. Approval is generally granted only to those children of the undocumented who were born abroad and have graduated from a U.S. high school, earned a GED, or who are still attending school. In Georgia, as elsewhere, those approved for deferred action receive authorization to work legally for two years. They also receive social security numbers and can apply for Georgia driver's licenses. Meanwhile, DREAM Act legislation, designed to special consideration to illegal immigrants who arrived as children, remains on hold, as do discussions of guest-worker programs that would allow the undocumented greater levels of entry into society (Gilbert, 2013).

Georgia, for its part, joined dozens of states in trying to rectify what it considered an abdication of responsibility by the federal government as state and local officials passed new laws targeting the undocumented, often on feeble constitutional grounds. They included limitations on access to work, denial of social services and housing, and generally restrictive measures often aimed at encouraging "self-deportation." These measures reflect sentiments that coalesced as previously non-Latino suburbs faced waves of newcomers. One recent Alabama statute tried unsuccessfully to undermine -if not reverse- the Supreme Court's 1982 ruling in Plyler v. Doe by seeking to deny that state's undocumented children full access to public education (Olivas, 2012). Notable in Texas is the case of Farmers Branch, located in the northwest Dallas metropolitan area, where restrictive housing practices date to 2006. In 
fall 2013, both Hazleton and Farmers Branch petitioned the U.S. Supreme Court for writs of certiorari, which, if granted, would pave the way for the Court to hear arguments on the constitutionality of local ordinances aimed at preventing unauthorized immigrants from working and renting property.

The total Latino population of Georgia as reported by the 2010 census reached 854 000, almost 9 percent of the state's residents (Scott, 2011), of whom an estimated 440000 were undocumented immigrants. There were fewer arrivals subsequently due to the economic downturn, yet metro Atlanta's overall Latino population has nearly doubled since the 2000 census as suburbs boomed. Gwinnett experienced the greatest Latino increase -from 64000 to 162000 - while formerly homogeneous rural areas suddenly became heterogeneous outer-ring suburbs. Still, the lives of the new immigrants may not be too far removed from those of earlier waves from other homelands, even though European immigrants settling in the East and Midwest tended to arrive via central cities teeming with tenement houses rather than by going directly to suburban apartments and single-family homes. Moreover, according to one historian, the twenty-first-century newcomers have become increasingly "unsettled" by the reception afforded them by their neighbors, as well as the instability of their lives owing to, among other factors, their undocumented immigration status. Yet suburban immigrant families in their new venues still need to support their families, take in visiting relatives, and sometimes rent to boarders to make ends meet. These contemporary immigrant manifestations require civil rights advocacy, a role that MALDEF filled locally. That experience offers historical precedent to help address the current absence of leadership (Odem, 2008: 122).

\section{BiblograPhy}

BADILlO, DAVID, A.

2005 "MALDEF and the Evolution of Latino Civil Rights," Research Report of the Institute of Latino Studies, University of Notre Dame, pp. 4-17.

BIXLER, MARK

2002 "Georgia's Hispanics: Changing of the Guard," The Atlanta Journal-Constitution, April 24, p. B5.

2001 "New Mexican Consul Takes Reins," The Atlanta Journal-Constitution, April 24, p. B4.

2000 "Advocate for State Latinos Retiring," The Atlanta Journal-Constitution, November 28, p. B5. 
1999 "Day Laborers in Roswell Get Place to Call Their Own," The Atlanta JournalConstitution, December 19, p. D1.

BLANCO, MARÍA

2013 Oral history interview with David Badillo, January 4.

Bohon, S. A., H. MacPherson, and J. H. Atiles

2005 "Educational Barriers for New Latinos in Georgia," Journal of Latinos and Education, vol. 4, no. 1, pp. 43-58.

BRETT, J.

2004 "Gwinnett Crime Preys on Hispanics," The Atlanta Journal-Constitution, January 10, p. A1.

Campos, C.

2006 "State Immigration Bill Faces Legal Threat," The Atlanta Journal-Constitution, March 30, p. D4.

CAMPOS, C., and T. ThARPE

2006 “Legislature 2006: First Face-Off on Illegals Debate,' The Atlanta Journal-Constitution, February 22, p. B1.

Dameron, Rebecca J., and Arthur D. Murphy

1997 "An International City Too Busy to Hate? Social and Cultural Change in Atlanta: 1970-1995," Urban Anthropology and Studies of Cultural Systems and World Economic Development, vol. 26, no. 1, pp. 44-69.

Durand, Jorge, Massey, S. Douglas, and Fernando Charvet

2000 "The Changing Geography of Mexican Immigration to the United States: 1910-1999," Social Science Quarterly, vol. 81, no. 1, pp. 1-15.

FEAGANS, B.

2005a “Fliers Tell Workers' Rights," The Atlanta Journal-Constitution May 10, p. JJ3.

2005b "Real ID Act Reroutes Drive for Licenses," The Atlanta Journal-Constitution, May 17, p. JJ2. 
GILBERT, LAUREN

2013 “Obama's Ruby Slippers: Enforcement Discretion in the Absence of Immigration Reform," West Virginia Law Review, vol. 116, no. 1, pp. 255-312.

JACKSON, KenNETH T.

1985 Crabgrass Frontier: the Suburbanization of the United States, New York, Oxford University Press.

JACOBS, S.

2006 "Latino State Senator to Blow Out of Politics," The Atlanta Journal-Constitution, April 6, p. C2.

MCCARTHY, ReBECCA

2004 "Immigration Status Not Local Matter: Police, Others Resist U.S. Legislation to Have Them Enforce Law," The Atlanta Journal-Constitution, May 17, p. JJ1.

Mohl, RAYMOnd A.

2003 "Globalization, Latinization, and the Nuevo New South," Journal of American Ethnic History, vol. 22, no. 4, pp. 31-66.

Moscoso, Eunice

2006 "Illegal Immigrant Laws Challenged: Rights Group Joins Hispanics in Suing Cities," The Atlanta Journal-Constitution, November 25, p. A3.

Odem, Mary E.

2008 "Unsettled in the Suburbs: Latino Immigration and Ethnic Diversity in Metro Atlanta," in A. Singer, S. W. Hardwick, and C. B. Brettell, eds., Twenty-firstcentury gateways: Immigrant Incorporation in Suburban America, Washington, D.C., Brookings Institution Press, pp. 105-136.

2004 "Our Lady of Guadalupe in the New South: Latino Immigrants and the Politics of Integration in the Catholic Church," Journal of American Ethnic History, vol. 24 , no. 1 , pp. $26-57$.

Odem, Mary, and Elaine Lacy

2009 "Introduction," in Mary E. Odem and Elaine Lacy, eds., Latino Immigrants and the Transformation of the U.S. South, Athens, Georgia, University of Georgia Press, pp. ix-xxviii. 
Olivas, Michael A.

2012 No Undocumented Child Left Behind: Plyler v. Doe and the Education of Undocumented Children, New York, New York University Press.

2011 "The Political Efficacy of Plyler v. Doe: the Danger and the Discourse," UC Davis Law Review, vol. 45, no. 1, pp. 1-26.

2007 "Immigration-related state and local ordinances: preemption, prejudice, and the proper role for enforcement," University of Chicago Legal Forum, pp. 27-56.

PICKEL, M. L.

2009 "Immigrants Lose Local Legal Office," The Atlanta Journal-Constitution, April 10, p. B1.

2008 "Law Cracks Down on License-less Driving: Immigrant Advocates Fear Unequal Enforcement," The Atlanta Journal-Constitution, May 31, p. B3.

2007 "Ex-Prosecutor to Lead Latino Community's Legal Rights Group," The Atlanta Journal-Constitution, July 11, p. D10.

Poole, S. M.

2006 "Cherokee in Line of Fire on Illegal Immigrants: Language, Rental Laws," The Atlanta Journal-Constitution, December 13, p. D1.

ReDMON, J.

2012 "'Show-Me-Your-Papers Law' a Go," The Atlanta Journal-Constitution, August 21, p. A1.

Robert Stewart v. Cherokee County, Georgia

2007 United States District Court for the Northern District of Georgia, Atlanta Division, January 4.

RODRIGUEZ, Y.

2002 "Latinos' Political Showing 'A Victory,'” The Atlanta Journal-Constitution, August 28, p. E1.

SALZER, J.

2013 "State Last in Latino Grads," The Atlanta Journal-Constitution, November 14, p. E1.

SANCE-VALVERDE, ISABEL

2005 Oral History Interview with David Badillo, April 11. 
SCOTT, J.

2011 “Region's Hispanic Population Doubles: Metro Atlanta Numbers Exceed Rise Statewide," The Atlanta Journal-Constitution, March 18, p. A14.

Singer, Audrey, Susan W. Hardwick, and Caroline B. Brettell

2008 "Afterword: Coming to Terms with Federal and Local Immigration Reform," in Twenty-First-Century Gateways: Immigrant Incorporation in Suburban America, Brookings Institution Press, Washington, D.C., pp. 308-317.

TALLMAN, TiSHA

2006 "Stop Anti-Immigrant Violence," The Atlanta Journal-Constitution, October 11, p. A15.

2005 Oral History Interview with David Badillo, April 11.

THARPE, JIM

2006 "Perdue Signs Bill on Illegals: Crackdown Law Faces Challenges," The Atlanta Journal-Constitution, April 18, p. A1.

VARELA, A.

2006 "Latino Defense Group Chief Quits: Mexican American Legal Defense and Educational Fund's Tisha Tallman Joins a Private Law Firm," The Atlanta Journal-Constitution, November 22, p. B3.

Walcott, Susan M., and Arthur Murphy

2006 "Latino Communities in Atlanta: Segmented Assimilation Under Construction," in Latinos in the New South: Transformations of Place, Burlington, Vermont, Ashgate Publishing, pp. 153-166.

WINDERS, JAMIE

2005 "Changing Politics of Race and Region: Latino Migration to the US South," Progress in Human Geography, vol. 29, no. 6, pp. 683-699.

Winders, JAMIE, and BARBARA E. SMITH

2012 "Excepting/Accepting the South: New Geographies of Latino Migration, New Directions in Latino Studies," Latino Studies, vol. 10, nos. 1-2, pp. 220-245. 
ZAMARRIPA, SAMUEL

2003 Oral History Interview with David Badillo, November 12.

ZWINGLE, ERLA

1988 "Atlanta on the Rise: Energy and Optimism in the New South," National Geographic, vol. 174, pp. 3-28. 